\title{
Liquid Chromatographic Method for Simultaneous Quantification of Alprazolam and Mebeverine in Pharmaceutical Dosage Form
}

Usmangani K Chhalotiya*, Nishma M Patel, Dimal A Shah, Falgun A Mehta and Kashyap K Bhatt

Department of Pharmaceutical Chemistry and Analysis, Indukaka Ipcowala College of Pharmacy, Gujarat, India

\begin{abstract}
A sensitive, rapid, accurate and reproducible Isocratic, RP-LC method was developed for determination of Alprazolam and Mebeverine in pharmaceutical dosage form. A Sunfire $C_{18}, 5 \mu \mathrm{m}$ column with mobile phase containing methanol: buffer $\left(0.02 \mathrm{M} \mathrm{KH}_{2} \mathrm{PO}_{4}\right)(70: 30)$. The flow rate was $1.0 \mathrm{ml} / \mathrm{min}$ and effluents were monitored at $225 \mathrm{~nm}$ with help of PDA detector. The retention time was $6.04 \mathrm{~min}$. for ALP and $3.53 \mathrm{~min}$. for MEB. The linearity was in the range of $0.05-40 \mu \mathrm{g} / \mathrm{ml}$ for ALP and $0.2-40 \mu \mathrm{g} / \mathrm{ml}$ for MEB. The proposed method was validated with respect to linearity, accuracy, precision, specificity and robustness. Due to simplicity, rapidity and accuracy of method, believe that the method will be useful for routine quality control analysis.
\end{abstract}

Keywords: Alprazolam; Mebeverine; RP-HPLC; Validation

\section{Introduction}

Alprazolam (ALP) is a white powder and amorphous in nature. Chemically it is 8-chloro-1-methyl-6-phenyl-4H-[1,2,4] triazolo [4,3,a]-[1,4] benzodiazepine[1] (Figure 1A). It is bind nonspecifically to benzodiazepine receptors BNZ-1, which mediates sleep, and BNZ-2, which affects muscle relaxation, anticonvulsant activity, motor coordination, and memory [2]. Mebeverine (MEB) is white powder. Chemically, it is 3, 4-Dimethoxybenzoic acid 4- [ethyl[2-(4methoxyphenyl)-1-methylethyl] amino]-butylester and both the drugs are very soluble in water and alcohol [3] (Figure 1B). Mebeverine act on the gut muscles at cellular level to relax them. This relieves painful muscles spasms of gut without affecting its normal motility. It is also an inhibitor of calcium depot replenishment [4]. Therefore it has dual mode of action which normalizes the small motility. The combination of Alprazolam with Mebeverine was useful and safe in irritable bowel syndrome.

Literature survey revealed that alprazolam can be estimated by spectrophotometry [5] and by liquid chromatographic methods [6-11] individually or in combination with other drugs, and mebeverine can be estimated by liquid chromatographic methods individually or in combination with other drugs [12-16]. The reported methods are highly sophisticated, costly, and time-consuming and require special sample preparation. In comparison to LC and other methods, HPLC method is considered to be a good alternative, and it should be widely explored as an important tool in routine drug analysis. UV Spectroscopy method has been reported for simultaneous estimation of both alprazolam and mebeverine in combined dosage form [17].

To our knowledge, no article related to the HPLC determination of ALP and MEB in pharmaceutical dosage forms has appeared in the

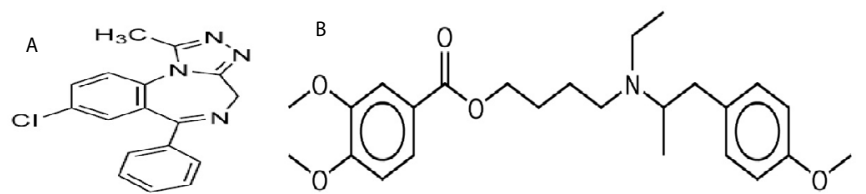

Figure 1: (A) Chemical Structure of Alprazolam (B) Chemical Structure of Mebeverine. literature. Present study involves development of a high performance thin layer liquid chromatographic method for the determination of ALP and MEB in combination dosage form. A major advantage of HPLC is its ability to analyze several samples simultaneously using a small quantity of mobile phase. This reduces the time and cost of analysis, minimizes exposure risks, and significantly reduces disposal problems of toxic organic solvents, thereby reducing the possibilities of environment pollution.

The aim of the present work was to develop an accurate, repeatable, and specific HPLC method for the determination of ALP and MEB both as a bulk drug and in formulation. The proposed method was validated according to ICH guidelines [18] and its updated international convention.

\section{Materials and Methods}

The liquid chromatographic system consist of Waters series 2998 (Shelton, USA) equipped with a PDA detector, series 515 quaternary isocratic pump and manual injector rheodyne valve with $20 \mu \mathrm{L}$ fixed loop. The analytes were monitored at $225 \mathrm{~nm}$. Chromatographic analysis was performed on Sunfire C18 column having $250 \mathrm{~mm} \times$ $4.6 \mathrm{~mm}$ i.d. and $5 \mu \mathrm{m}$ particle size. All the drugs and chemicals were weighed on Mettler Toledo electronic balance (ME204/A04, Mettler Toledo Group).

Analytically pure ALP and MEB were obtained as gift samples from Sun Pharmaceutical Pvt. Ltd., Baroda, India. Methanol (HPLC Grade) SRL Private Ltd. Mumbai, India and Potassium Dihydrogen Ortho Phosphate Buffer - S. D. Fine Pvt. Ltd., Mumbai, India was obtained.

*Corresponding author: Usmangani K Chhalotiya, Department of Pharmaceutical Chemistry and Analysis, Indukaka Ipcowala College of Pharmacy, New Vallabh Vidyanagar -388121, Gujarat, India, E-mail: usmangani84@gmail.com

Received April 30, 2015; Accepted June 02, 2015; Published June 09, 2015

Citation: Chhalotiya UK, Patel NM, Shah DA, Mehta FA, Bhatt KK (2015) Liquid Chromatographic Method for Simultaneous Quantification of Alprazolam and Mebeverine in Pharmaceutical Dosage Form. Pharm Anal Acta 6: 381 doi:10.4172/21532435.1000381

Copyright: (c) 2015 Chhalotiya UK, et al. This is an open-access article distributed under the terms of the Creative Commons Attribution License, which permits unrestricted use, distribution, and reproduction in any medium, provided the original author and source are credited. 
Citation: Chhalotiya UK, Patel NM, Shah DA, Mehta FA, Bhatt KK (2015) Liquid Chromatographic Method for Simultaneous Quantification of Alprazolam and Mebeverine in Pharmaceutical Dosage Form. Pharm Anal Acta 6: 381. doi:10.4172/21532435.1000381

Page 2 of 6

\section{Chromatographic conditions}

The Sunfire C18 column equilibrated with mobile phase methanol: buffer (0.02M Potassium Dihydrogen Ortho Phosphate Buffer) (70:30) was used. The flow rate was maintained at $1 \mathrm{~mL} / \mathrm{min}$, eluent were monitored with PDA detector at $225 \mathrm{~nm}$, and the injection volume was $20 \mu \mathrm{L}$. Total run time was kept $8 \mathrm{~min}$.

\section{Preparation of standard stock solutions}

Alprazolam and Mebeverine were weighed $(10 \mathrm{mg})$ and transferred to $10 \mathrm{ml}$ volumetric flask containing few $\mathrm{ml}$ of methanol. Volume was made up to the mark with methanol to yield a solution containing 1000 $\mu \mathrm{g} / \mathrm{ml}$ of alprazolam and mebeverine. Aliquot from the stock solution were appropriately diluted with mobile phase to obtain working standard of $100 \mu \mathrm{g} / \mathrm{ml} \mathrm{ALP}$ and MEB.

\section{Method Validation}

The method was validated for accuracy, precision, linearity, detection limit, quantitation limit and robustness.

\section{Linearity}

Appropriate aliquots of ALP and MEB working standard solution was taken in different $10 \mathrm{~mL}$ volumetric flasks and diluted up to the mark with mobile phase to obtain final concentrations of 0.05 , $0.5,5,10,20,40 \mu \mathrm{g} / \mathrm{mL}$ of ALP and $0.2,0.5,5,10,20,40 \mu \mathrm{g} / \mathrm{mL}$ of MEB. The solutions were injected using a $20 \mu \mathrm{L}$ fixed loop system and chromatograms were recorded. Calibration curves were constructed by plotting average peak area versus concentrations and regression equations were computed $(n=5)$.

\section{Precision}

The repeatability study was carried out by estimating response six times and results are reported in terms of relative standard deviation. The intra-day and inter-day precision study (intermediate precision) was carried out by estimating the responses 3 times on the same day and on 3 different days for three different concentrations of $0.05,5,20$ of ALP and 0.2, 5, 20 of MEB and the results are reported in terms of relative standard deviation.

\section{Accuracy}

The accuracy of the method was determined by calculating recovery of ALP and MEB by method of standard addition. Known amount of $\operatorname{ALP}(0,0.05,0.1,0.15 \mu \mathrm{g} / \mathrm{mL}), \operatorname{MEB}(0,5,10,15 \mu \mathrm{g} / \mathrm{mL})$ were added to a pre quantified sample solution, and the amount of ALP and MEB were estimated by measuring the peak areas and by fitting these values to the straight-line equation of calibration curve.

\section{Detection limit and quantitation limit}

The limit of detection (LOD) is defined as the lowest concentration of an analyte that can reliably be differentiated from background levels. Limit of quantification (LOQ) of an individual analytical procedure is the lowest amount of analyte that can be quantitatively determined with suitable precision and accuracy. LOD and LOQ were calculated using following equation as per ICH guidelines.

$$
\mathrm{LOD}=3.3 \times \sigma / \mathrm{S} ; \mathrm{LOQ}=10 \times \sigma / \mathrm{S} ;
$$

Where $\sigma$ is the standard deviation of y-intercepts of regression lines and $\mathrm{S}$ is the slope of the calibration curve.

\section{Specificity}

The specificity was estimated by spiking commonly used excipients (starch, talc and magnesium stearate) into a pre weighed quantity of drug. The chromatogram is taken by appropriate dilutions. Developed spot area and retention time of ALP and MEB were determined and effect of interfering compound was investigated.

\section{Robustness}

Robustness of the method was studied by deliberately changing the experimental conditions like flow rate and percentage of organic phase.

\section{Solution stability}

Stability of sample solutions were studied at $25 \pm 2^{\circ} \mathrm{C}$ for $24 \mathrm{~h}$.

\section{System suitability}

A system suitability test was an integral part of the method development to verify that the system is adequate for the analysis of ALP and MEB to be performed. System suitability test of the chromatography system was performed before validation run. Six replicate injections of a system suitability standard and one injection of a check standard were made. Area, retention time (Rt), capacity factor, column efficiency, symmetric factor, and signal to noise ratio for the five suitability injections were determined.

\section{Analysis of marketed formulation}

Twenty tablets were weighed accurately and finely powdered. Tablet powder equivalent to $0.25 \mathrm{mg}$ ALP and $135 \mathrm{mg}$ of MEB were taken in $10 \mathrm{ml}$ volumetric flask. Methanol $(5 \mathrm{ml})$ was added to the above flask and the flask was sonicated for 10 minutes. The solution was filtered using Whatman filter paper No.41 and volume was made up to the mark with the mobile phase.

Appropriate volume of the aliquot was transferred to a $10 \mathrm{ml}$ volumetric flask and the volume was made up to the mark with the mobile phase to obtain a solution containing $0.1 \mu \mathrm{g} / \mathrm{ml}$ of ALP and 54 $\mu \mathrm{g} / \mathrm{ml}$ of MEB. The solution was sonicated for $10 \mathrm{~min}$. It was injected as per the above chromatographic conditions and peak area were recorded. The quantification was carried out by keeping this value to the straight line equation of calibration curve.

\section{Results and Discussion}

\section{Optimization of mobile phase}

The objective of the method development was to achieve chromatographic peaks for active drug ingredients with less asymmetric factor. The mobile phase methanol: buffer( $0.02 \mathrm{M}$ Potassium Dihydrogen Ortho Phosphate Buffer) $(70: 30 \% \mathrm{v} / \mathrm{v})$ was found to be satisfactory which gave symmetric peak. Overlaid UV spectra of the drugs showed that ALP and MEB absorbed appreciably at $225 \mathrm{~nm}$ (Figure 2), so detection was carried out at $225 \mathrm{~nm}$. The retention time for ALP was $3.53 \mathrm{~min}$. and MEB was $6.04 \mathrm{~min}$ (Figure 3). The asymmetric factor for ALP and MEB was 0.45 and 0.57 , respectively. The mobile phase flow rate was maintained at $1 \mathrm{~mL} / \mathrm{min}$. Overlain chromatograms of ALP and MEB were shown in Figure 4.

The calibration curve for ALP and MEB was found to be linear in the range of $0.05-40 \mu \mathrm{g} / \mathrm{ml}$ and $0.2-40 \mu \mathrm{g} / \mathrm{ml}$ with a correlation coefficient of 0.995 and 0.999 . The summary of validation and system suitability parameters were shown in Table 1 .

The intra-day and inter-day precision studies were carried out. The low RSD value indicate that the method is precise. The accuracy of the method was determined by calculating recovery of ALP and MEB by method of standard addition. The percentage recovery was found to be 
Citation: Chhalotiya UK, Patel NM, Shah DA, Mehta FA, Bhatt KK (2015) Liquid Chromatographic Method for Simultaneous Quantification of Alprazolam and Mebeverine in Pharmaceutical Dosage Form. Pharm Anal Acta 6: 381. doi:10.4172/21532435.1000381

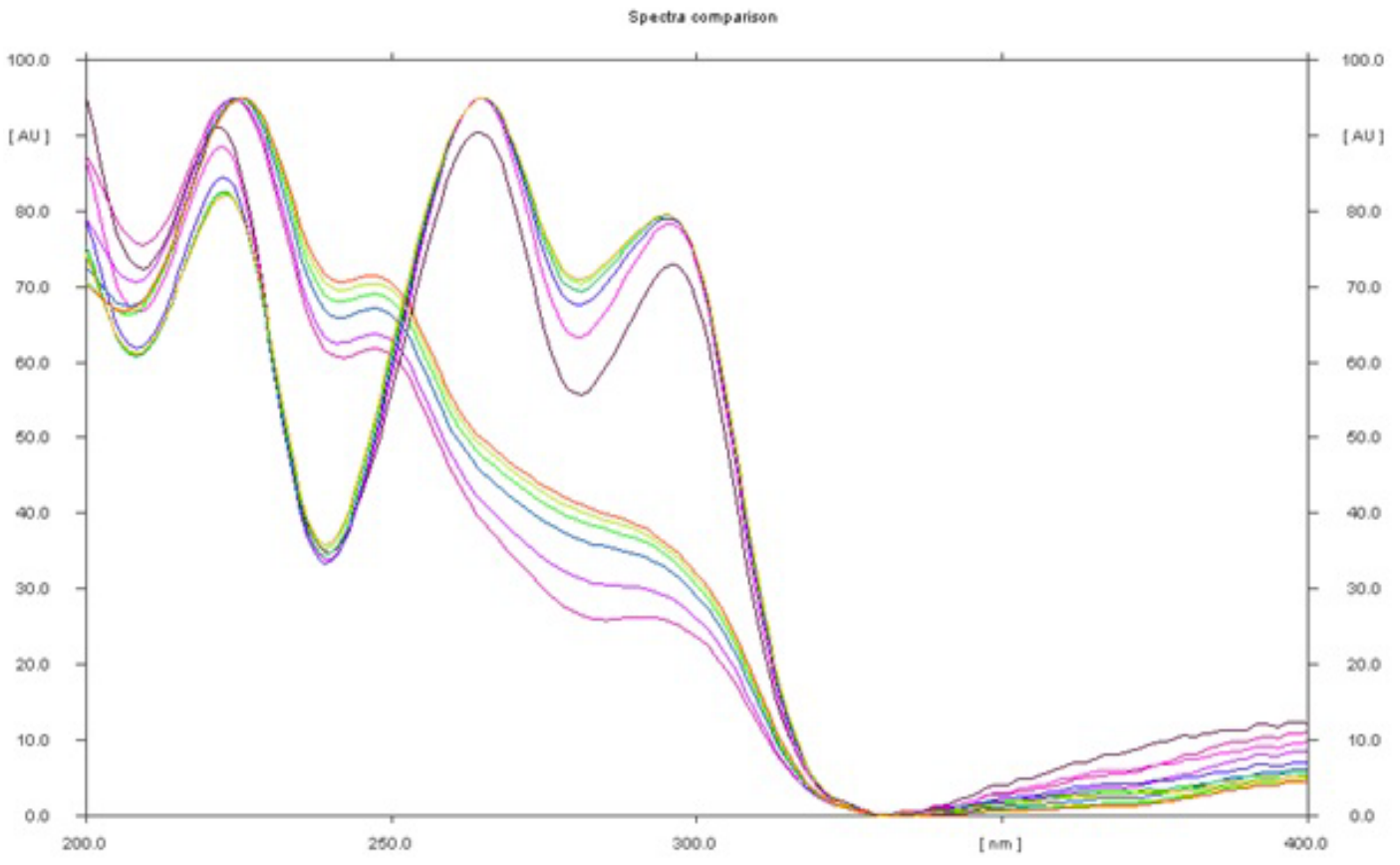

Figure 2: Overlain UV - Visible spectrum of ALP and MEB.

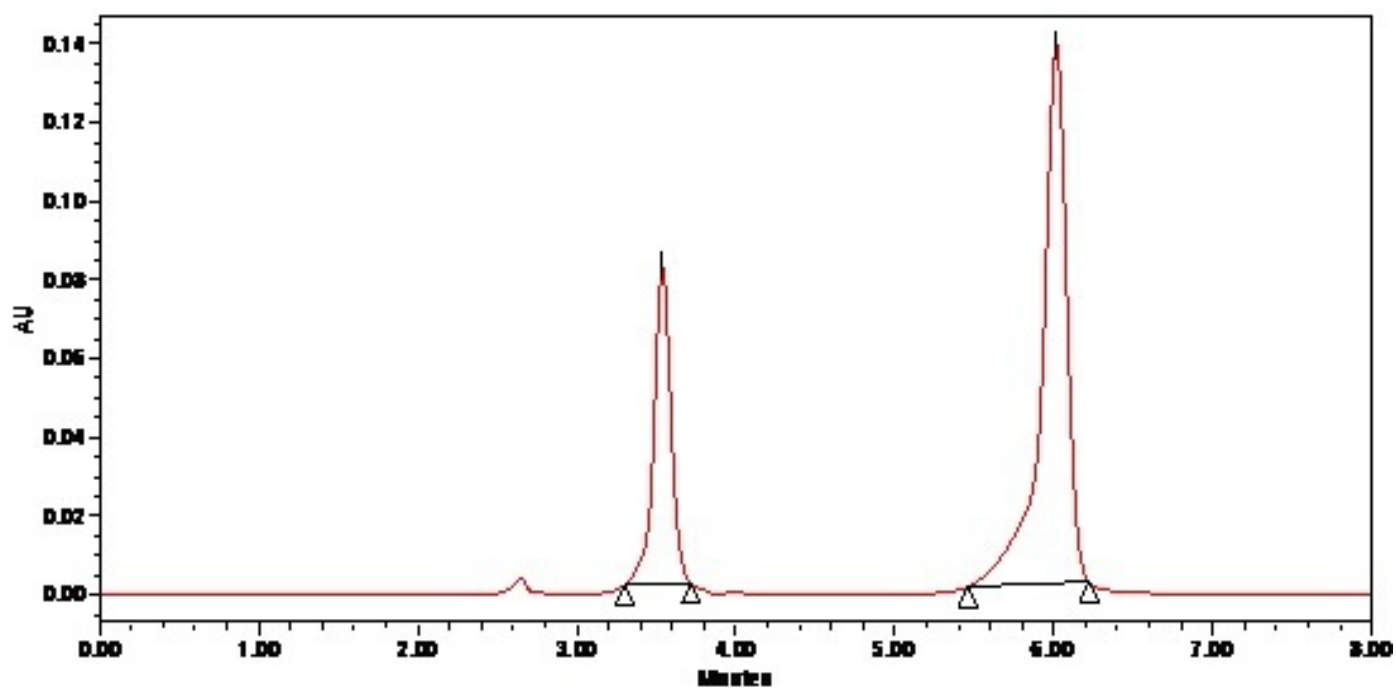

Figure 3: Chromatogram of Standard ALP $(10 \mu \mathrm{g} / \mathrm{ml})$ and MEB $(10 \mu \mathrm{g} / \mathrm{ml})$.

98.29-101.39 for ALP and 99.42 - 100.55 for MEB, respectively. This values indicate that the method is accurate (Table 2).

The detection limit for ALP and MEB was found to be 0.080 $\mu \mathrm{g} / \mathrm{mL}$ and $0.016 \mu \mathrm{g} / \mathrm{mL}$, respectively, while quantitation limit was found to be $0.243 \mu \mathrm{g} / \mathrm{mL}$ and $0.050 \mu \mathrm{g} / \mathrm{mL}$, respectively The above data shows that a nano gram quantity of the drug can be accurately and precisely determined. Robustness study was performed by deliberately changing the experimental conditions like flow rate from $1 \mathrm{ml} / \mathrm{min}$ to $0.8 \mathrm{ml} / \mathrm{min}$ and $1.2 \mathrm{ml} / \mathrm{min}$. The composition of mobile phase was changed varying the proportion of methanol by 2
$\%$. In both the conditions the recovery of the drug was determined and the RSD was found to be less than $2 \%$ (Table 3). Stability of standard and sample solution of ALP and MEB were evaluated at room temperature for $24 \mathrm{hr}$. The drug was found to be stable with a amount of drug found more than $98 \%$.

The proposed method was successfully applied to the determination of ALP and MEB in its dosage form. The \% recovery was found to be 100.5110 .58 and $100.55 \pm 1.08$, respectively which was comparable with the labeled amount $(n=3)$ (Table 4$)$. The chromatogram of marketed formulation was shown in Figure 5. 
Citation: Chhalotiya UK, Patel NM, Shah DA, Mehta FA, Bhatt KK (2015) Liquid Chromatographic Method for Simultaneous Quantification of Alprazolam and Mebeverine in Pharmaceutical Dosage Form. Pharm Anal Acta 6: 381. doi:10.4172/21532435.1000381

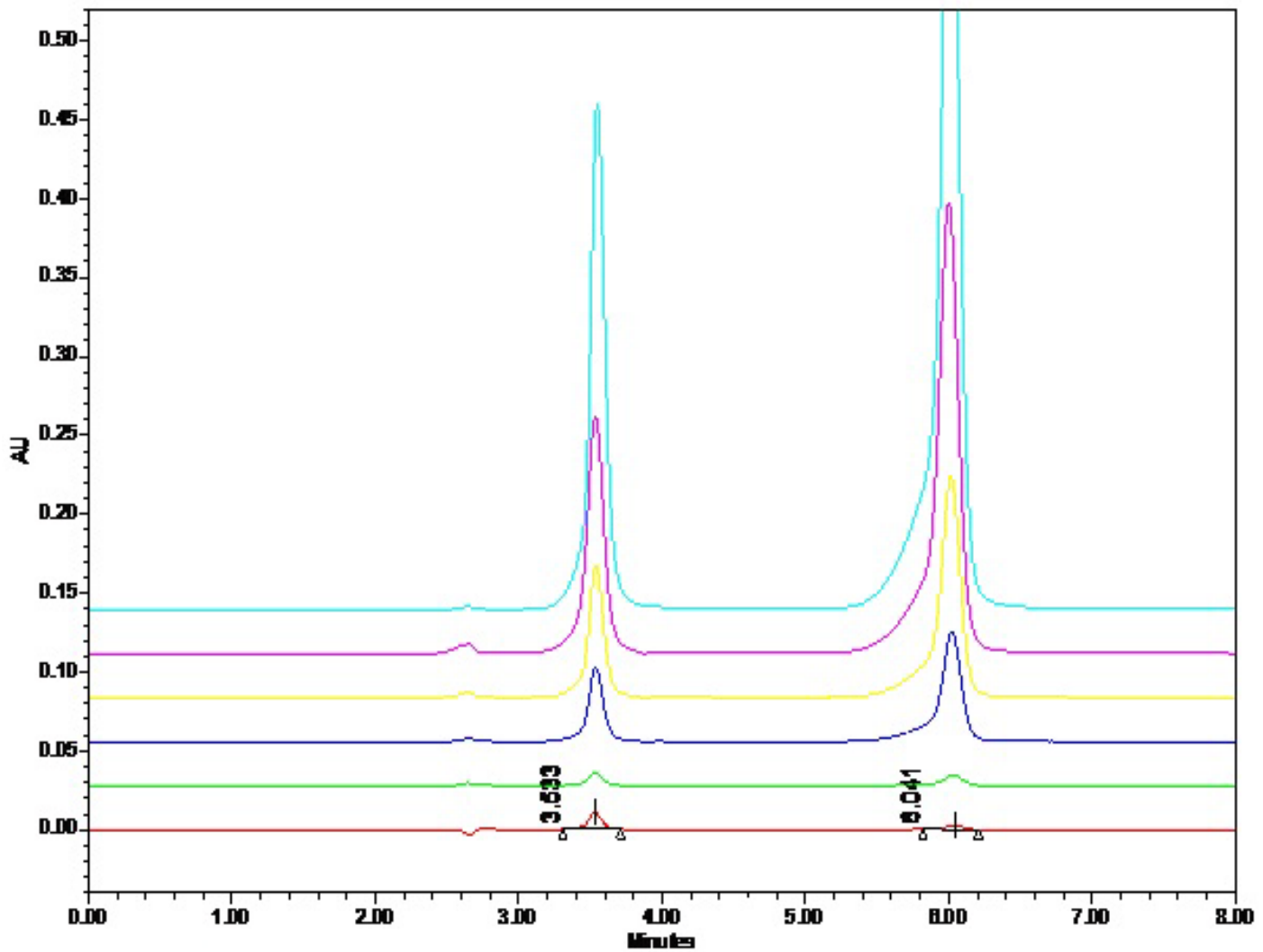

Figure 4: Overlay Chromatogram of ALP $(0.05-40 \mu \mathrm{g} / \mathrm{ml})$ and MEB $(0.2-40 \mu \mathrm{g} / \mathrm{ml})$.

\begin{tabular}{|c|c|c|}
\hline Parameters & ALP & MEB \\
\hline Linearity ( $\mu \mathrm{g} / \mathrm{ml})$ & $0.05-40$ & $0.2-40$ \\
\hline Retention Time (min) & 6 & 3.5 \\
\hline Detection limit ( $\mu \mathrm{g} / \mathrm{ml})$ & 0.08 & 0.01 \\
\hline Quantitation limit $(\mu \mathrm{g} / \mathrm{ml})$ & 0.24 & 0.05 \\
\hline Accuracy (\%) & $99.42-100.55$ & 98.29-101.39 \\
\hline \multicolumn{3}{|c|}{ Precision (\%RSD) } \\
\hline Intra-day $(n=3)$ & $0.70-1.31$ & $0.69-1$ \\
\hline Inter-day $(n=3)$ & $0.82-1.81$ & $1.14-1.82$ \\
\hline Specificity & Specific & Specific \\
\hline Robustness & Robust & Robust \\
\hline Solvent suitability & Suitable for 24 hrs. & Suitable for $24 \mathrm{hrs}$. \\
\hline Retention time(min) & 6.04 & 3.53 \\
\hline Theoretical Plates & 5053 & 6903 \\
\hline Asymmetric factor & 0.45 & 0.57 \\
\hline Resolution & \multicolumn{2}{|c|}{2.57} \\
\hline
\end{tabular}

Table 1: Summary Of Validation And System Suitability Parameters

\begin{tabular}{|c|c|c|c|c|c|c|}
\hline \multirow[b]{2}{*}{ Level } & \multicolumn{2}{|c|}{$\begin{array}{l}\text { Amount Added } \\
(\mu \mathrm{g} / \mathrm{ml})\end{array}$} & \multicolumn{2}{|c|}{$\begin{array}{c}\text { Amount Recovered } \\
(\mu \mathrm{g} / \mathrm{ml})(\mathrm{n}=3)\end{array}$} & \multicolumn{2}{|c|}{$\%$ Recovered \pm S.D } \\
\hline & MEB & ALP & MEB & ALP & $\%$ MEB & $\%$ ALP \\
\hline 0 & $10+0$ & $0.1+0$ & 10.05 & 0.10 & $100.55 \pm 1.08$ & $101.39 \pm 4.06$ \\
\hline 50 & $10+5$ & $0.1+0.05$ & 14.99 & 0.14 & $99.98 \pm 1.44$ & $98.29 \pm 3.92$ \\
\hline 100 & $10+10$ & $0.1+0.1$ & 19.94 & 0.20 & $99.42 \pm 1.51$ & $100.49 \pm 5.97$ \\
\hline 150 & $10+15$ & $0.1+0.15$ & 24.99 & 0.24 & $99.96 \pm 1.51$ & $99.23 \pm 7.58$ \\
\hline
\end{tabular}

Table 2: Accuracy Study Of Alp And Meb By Proposed Rp-Lc Method. 
Citation: Chhalotiya UK, Patel NM, Shah DA, Mehta FA, Bhatt KK (2015) Liquid Chromatographic Method for Simultaneous Quantification of Alprazolam and Mebeverine in Pharmaceutical Dosage Form. Pharm Anal Acta 6: 381. doi:10.4172/21532435.1000381

Page 5 of 6

\begin{tabular}{|c|c|c|c|c|}
\hline \multirow{2}{*}{ Method Parameter } & \multirow{2}{*}{ Normal Condition } & \multirow{2}{*}{ Deliberate Change } & \multicolumn{2}{|c|}{$\%$ RSD of peak area $(n=3)$} \\
\hline & & & ALP & MEB \\
\hline \multirow{2}{*}{ Flow rate } & \multirow{2}{*}{$1.0 \mathrm{ml} / \mathrm{min}$} & $0.8 \mathrm{ml} / \mathrm{min}$ & 0.49 & 1.14 \\
\hline & & $1.2 \mathrm{ml} / \mathrm{min}$ & 0.60 & 1.06 \\
\hline \multirow{2}{*}{ Mobile phase ratio } & \multirow{2}{*}{ Methanol: Buffer (70:30) } & $72: 28$ & 1.01 & 1.90 \\
\hline & & $68: 32$ & 1.12 & 1.81 \\
\hline \multirow{2}{*}{$\mathrm{pH}$ of mobile phase ratio } & \multirow{2}{*}{5.0} & 5.2 & 0.58 & 0.67 \\
\hline & & 4.8 & 0.69 & 1.02 \\
\hline
\end{tabular}

Table 3: Robustness Data For Alp and Meb By Proposed Rp- Lc Method.

\begin{tabular}{|l|c|c|c|c|c|}
\hline \multirow{2}{*}{$\begin{array}{c}\text { Formulation } \\
\text { MEBASPA- AL }\end{array}$} & \multicolumn{3}{|c|}{ Amount drug taken $(\mu \mathrm{g} / \mathrm{mL})$} & \multicolumn{2}{|c|}{$\begin{array}{c}\text { Amount of drug found } \\
\text { Mean } \pm \text { SD* } \\
(\mathrm{n}=3)\end{array}$} \\
\cline { 2 - 6 } & ALP & MEB & ALP & MEB & 10.05 \\
\hline
\end{tabular}

Table 4: Analysis of Marketed Formulation.

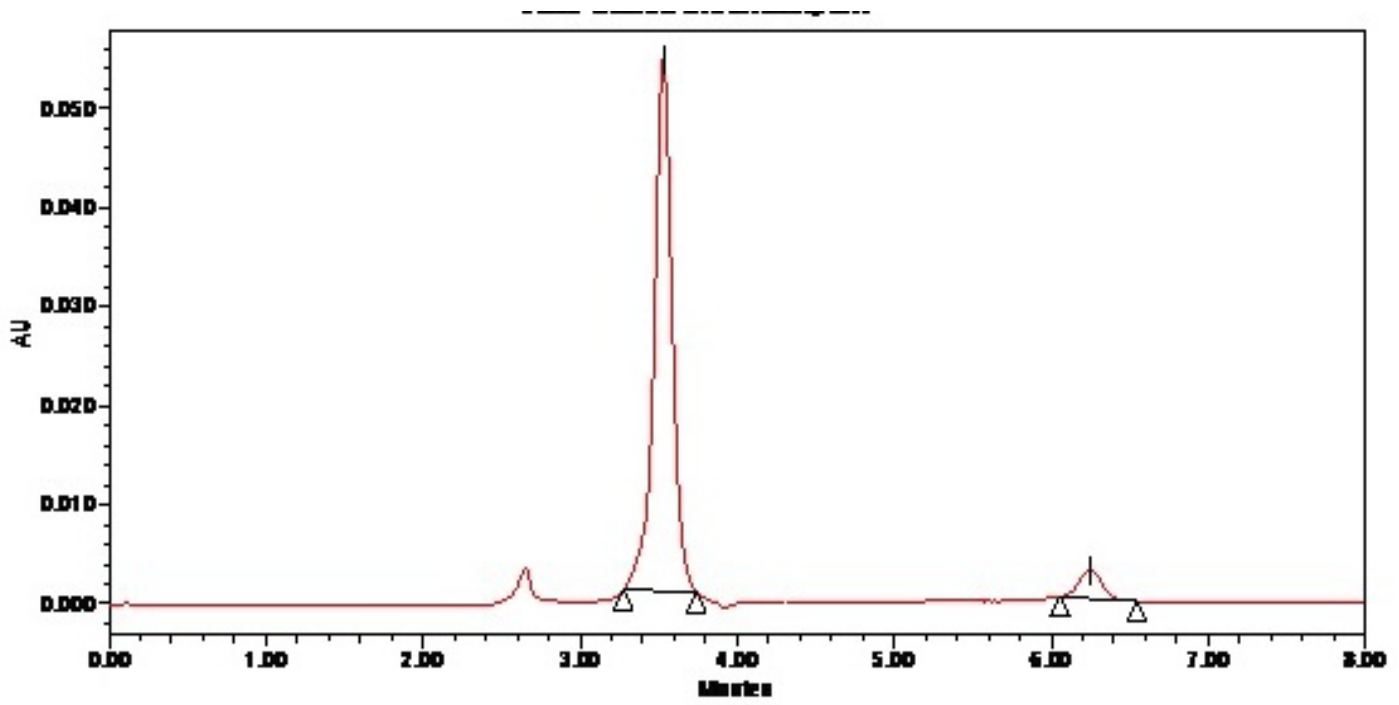

Figure 5: Chromatogram of marketed formulation ALP $(0.1 \mu \mathrm{g} / \mathrm{ml})$ and MEB $(10 \mu \mathrm{g} / \mathrm{ml})$.

\section{Conclusion}

Proposed study describes RP-LC method for the simultaneous quantification of ALP and MEB in its formulation. The method was validated and found to be simple, sensitive, accurate and precise. Statistical analysis proved that method was repeatable and selective for the simultaneous analysis of ALP and MEB without any interference from the excipients. The method was successfully used for determination of drug in their formulation.

\section{Acknowledgments}

The authors are very thankful to Principal, Indukaka Ipcowala College of Pharmacy, New Vallabh Vidyanagar for providing necessary facilities to carry out research work.

\section{References}

1. Drug information of alprazolam http://www.drugbank.ca/drugs/DB00404

2. Sharma HL, Sharma KK (2007) Principles of pharmacology ( $1^{\text {st }}$ edn) Paras publishing, 406-407.

3. Drug information of mebeverine https://pubchem.ncbi.nlm.nih.gov/compound/4031
4. Sharma HL, Sharma HL (2007) Principles of pharmacology ( $\left(^{\text {st }}\right.$ edn) Paras publishing, 452-453.

5. (2007) Indian pharmacopoeia: Ministry of Health and Family Welfare Government of India, Published by The controller of publications Delhi 2: 78-79

6. Hanysova L, Grafnetterova T, Dubovska M, Klimes J (2005) Development of the analytical method for LCMS detection of unknown degredation product of alprazolam. J Pharm Chem 59: 99-102.

7. Bais S, Bhavsar M, Singhvi I, Chandewar A (2014) Analytical method development and validation for the estimation of alprazolam and sertraline hydrochloride by HPLC. The Pharma Res 11: 10-23.

8. Perez-Lozano P, Garcia-Montoya E, Orriols A, Minarro M, Tico JR (2004) Development and validation of a new HPLC analytical method for the determination of alprazolam in tablets. J Pharm Biomed Anal 10: 979-987.

9. Sharma S, Sharma MC (2011) Method development and validation of UV spectroscopic method for alprazolam in pharmaceutical dosage form using ferric chloride and indigo carmine. European J Appl Sci 3: 81-85.

10. Chaudhary J, Jain A, Saini V (2012) Analytical method development and validation for the simultaneous estimation of alprazolam and propranolol in their combined dosage form, Int J Drug Del 4: 310-315.

11. Wagh JG, Ahuja D, Banerjee A (2014) Development and validation of analytical methods for alprazolam and fluoxetine in pharmaceutical dosage form. American journal of pharma tech 4: 620 - 634 . 
Citation: Chhalotiya UK, Patel NM, Shah DA, Mehta FA, Bhatt KK (2015) Liquid Chromatographic Method for Simultaneous Quantification of Alprazolam and Mebeverine in Pharmaceutical Dosage Form. Pharm Anal Acta 6: 381. doi:10.4172/21532435.1000381

12. (2007) Indian pharmacopoeia: Ministry of Health and Family Welfare, Government of India, Published by The controller of publications Delhi 2: 722723.

13. Radwan MA, Abdine HH, Hassan YA (2006) A validated chiral HPLC method for the determination of mebeverine $\mathrm{HCL}$ enantiomers in pharmaceutical dosage forms and spiked rat plasma. Research Gate 20: 211-218.

14. Arayne MS, Sultana N, Siddiqui FA (2005) A new RP-HPLC method for analysis of mebeverine hydrochloride in raw materials and tablets. Pak J Pharm Sci 18: $11-14$

15. Kothapelly Rm, Nalluri LP, Gaddam V, Rachawar N, Akuthota A (2006) UV spectrophotometric method development and validation for the simultaneous quantitative estimation of mebeverine hydrochloride and chlordiazepoxide in capsules. Int J Pharm and Pharmaceutical Sci 6: 345-349.

16. Reddy PR, Reddy VK, Reddy GE, Ramachandra SY (2014) Development and validation of a Ultra Performance Liquid Chromatographic method for assay of mebeverine hydrochloride. Int J Pharm and Pharmaceutical Sci 6: 442-445.

17. Makwana DH, Patel PB (2013) Development and validation of spectroscopic methods for simultaneous estimation of alprazolam and mebeverine hydrochloride in bulk drug and pharmaceutical dosage form. Indo American J Pharma Res 3: 4605-4616.

18. (2005) ICH-Guidelines Q2(R1), Validation of Analytical Procedures: Text and Methodology, Geneva, Switzerland. 